\author{
M.K. Zhunusova, A.Zh. Sayazhanova \\ Karagandy University of the name of E. A. Buketov, Kazakhstan \\ (E-mail: zhunusovaMK@mail.ru,saya_aibota@mail.ru)
}

\title{
The syntactic structure of the initial and final sentences
}

\begin{abstract}
The article analyzes the key role of syntactic features in the composition of the text. It was determined that the first and last sentences of the text are syntactically diverse. Sentence words, simple, introductory, and complex sentences perform communicative, expressive, and stylistic functions in the text. The semantic and compressed structures, modality, expressiveness, and stylistic skills that are based on various structures of these sentences were studied to reveal the clarity and comprehensibility of the idea of sentences. It is emphasized that with the help of syntactic laws, by means of one-or two-part sentences that convey the idea of the text, the features of the character are briefly and concisely revealed. The features of the formation of various initial sentences are defined. The syntactic structure of initial and final sentences is different: simple, ambiguous, complete, incomplete, positive, negative. All types of single-part components are nominal, vocative, and non-articulate sentences. However, such sentences are not complex, they are mostly simple short sentences. Semantic and syntactic characteristics of initial and final sentences are described in their idiomatic, narrative, interrogative, and complex forms. It was determined by the semantic properties of rhetorical questions in the initial proposals. It should be noted that the nominal structure of the initial sentences of the text is used not only for ease of description but also for emotionality as if it is related to certain aspects of the plot or the general content of the story and affects the reader's feelings. It is believed that the authors in the initial sentences not only indicate the time or place of the event, but also describe human behavior in relation to the environment and nature, and thus allow the reader to predict the end of the story. It was ascertained that the initial and final sentences, depending on the historical period, can be used in both positive and negative meanings.
\end{abstract}

Keywords: syntactic features, simple sentence, semantics, stylistic skill, initial sentences, final sentences, text, composition, syntactic regularity.

\section{The syntactic structure of the initial and final sentences}

«Syntax is a living indicator of a literary text» $[1 ; 43]$. At the same time, its structure, communicative, expressive, stylistic activity in text formation, first of all, is closely related to the genre of the work, the idea, features, the ability of the author, and other various conditions associated with them. Specific data can be provided for this purpose.

For example, in the work of academician V.V. Vinogradov on the language of fiction in the article of the researcher A.V. Chicherin on the novel by L. N. Tolstoy «Dekabrister»: «The novel begins with a period containing 698 words formed in closely interrelated complex sentences» $[2 ; 250]$, the scientist M. Bazarbayev writes: «In the novel «Urker» by Abish Kekilbayev, there are sentences composed of 167 words» [3; 64]. And I.R. Galperin chairman of the economic Commission at the UN 10. IX. One of the sentences of 1955 contains 66 full-meaning words that were composed only by one adjacent complex expression, called a sentence-text $[4 ; 33]$. Now the next day after the transfer to the theater of the play «Apalysinililer» from A.P. Chekhov crossed out two points of a wonderful monologue of the screenwriters, he wrote «A wife is a wife!» («Ayelin degen - ayelin!») one replacement received a letter of appeal is said by the word [5;254].

About the first of them V. Vinogradov said: «Do not confuse the syntactic form and semantic content of speech», - but, about the second R. Syzdyk said: «In the author's story (tells about the same novel «Urker»), many long sentences are often found and they often make up the text expressed by the thought, understanding, and look of the hero. These «suiegi auyrlau» phrases are found throughout the novel, since this work is transmitted not only from the author's name, but from the thoughts, memories, and predictions of the characters... It is not necessary to consider which of the sentences are simple or long, complex or not. Not to mention the stylistic demand and the combination of the language type, the harmony of the content ...» $[1 ; 89,90]$.

The two previous references are based on extensive epics, the third on an official document, and the fourth on the nature of the dramatic work. The secret of the latter is revealed by academician $\mathrm{Z}$. Kabdolov: 
«Drama language is concise and short. After all, the truth described in a novel on one page must be conveyed in a single word in the play», the scientist says that the requirements for the language of the story genre are very high: «The story should be written so that there is nothing to add... the speech, first, should be short, and second, skilful» [5; 345] - quotes statements that the shortest of them can be read within ten minutes, and the classic model should not exceed seven to eight pages. It is obvious that these writers are of particular importance. For example, the shortest of the stories that we studied is the half-page by M. Omar (Zhymbak), and the longest-33-sheet works of A. Kekilbayev (Akirgy aialdama). Thus, we will make sure that the syntax of a work of art is formed from the above, mainly depending on the genre of the work. As you know, in the style of a work of art, even in any of the oral, written forms of a common phrase, there should be, as far as possible, a requirement to present with a communicative unit with a decent semantic, compact structure.

bout the role and functions of compact, short writing in the system of the phrase K. Onalbayeva said: «Earlier, the sentences were shorter, more accurate, more convincing than the long words. The evidence for this is that proverbs and sayings in our literature, teaching-speaking winged words, sentences, and most of the sentences are simple sentences consisting of 3-4 words. Therefore, such sentences are very effective for use, and they are made worth remembering, since there are no extra words in the sentences. Sentences formed only from the necessary words» [6;7], A. Akyzhanova said: «The modern style of literary works is characterized by compactness, continuity of sentences» [7;51].

N. H. Demesinova told about the problem of compactness: «The modern Kazakh language is a striving for maximum compression and compactness of syntactic structures... She writes that the creation of such syntactic constructions is based on the principle of simplifying visual means, reducing the number of members that do not have special semantic loads from the sentence» $[8 ; 36]$.

Although proverbs and sayings, as well as winged words, maxims, scientific definitions, etc., were compact examples, but artistic sentences do not always have to be at the same time complete and build only the same thing as the initial, consisting of narrative words. Since « a sentence basically assumes that a category is allocated depending on the nature and scope of thought» [2; 254-257], and «short-term revelation of sentences often pursues a stylistic goal» $[1 ; 44]$. Thus, it is understood that the syntax of the text, as well as the interpretation, is a diverse phenomenon.

Most of the original sentences of the short stories that we consider were compact, few in number, precise chosen words in relation to thoughts, impressive spent, without extra words. The reason for this is, of course, as it was mentioned above, is due to the peculiarities of the genre of the story, the stylistic requirement of the text.

Non-extended sentence. The definitions given therein are not uniform. For example, M. Balakaev: «The members that make up non-extended sentence will only be initial and narrative (or one of them)» [9; 70], - however, R. Amir says: «The organizational leaven of a sentence is the members that have a predicative relation, expressing a predicative meaning... The dictionary of O. S. Akhmanov describes as «A sentence that does not contain indefinite terms», as well as « Night. The silence» enclosed in the address to nonextended sentence $[2 ; 270]$. And in the encyclopedia, the sentence «the stepmother loves» is given as an example of this non-extended sentence.

In conversations, which studied sentences created only from the initial and predicate, we rarely encountered: 1. The snow began to thicken (E. Konarbaev, Zhapalak-zhapalak kar zhauar). 2. The day is rainy (A. Ibragimov, Bizdin auildyn azhyrygy). 3. Kazakh is hospitable. (A. Ibragimov, Zhuas zhezde). 4. It just did not break. (D. Doszhan, Pilmen kuresy). 5. He had a dream. (D. Duisenbiyev, Ulken kalanin konagy).

The proposals are formulated only from stable, compact, at the same time clear, and understandable information characteristics. They are the following typical examples:

1. The people went quiet. The meeting opened (Sh. Murtaza, Tastai berik, guldei nasik). 2. Aibol is happy. Guests are also very glad. Saule and Sholpan started singing (A. Shamkenov, Matel). 3. Everything is as usual (D. Ashimkhanuly, Akkabanyn tolkyny).

They contain all the main members, which by their nature, in relation to the sides of the word, are different in composition: one is completely empty, the second is initial, the report is complex or unified; most of the nouns, some of the adjectives (happy, glad), and formed from a noun and verb combination (started singing).

Extended sentence. The authors of the textbook consider this type of sentence as» the main condition to be part of the primary, in addition to the narrative members or one of them «. Here are some of the examples we find in this context: 1. Sengirtau - one frontier of the Kazakh land (K. Zhumalilov, Akburanyn asuy). 2. He is the only one in his office (M. Skakbaev, Menin korshi ariptesim). 3. People say our village has long 
ago called Aksai (Sh. Murtaza, Aksai men Koksay) 4. Houses surrounded by tent camps seemed to be a modern village (K. Junisbek, Kulik).

The first sentence « Kazakh land « has an independent definition of ownership, the second sentenceaddress (office), amal (single) with modifications, five words in the third sentence have separate functions of five members, in the fourth sentence their functions are performed by eleven words (distinguished by symbols).

Complete and incomplete sentences. This description has its own characteristic: the presence of all members that can be published. But we say: «In a sentence, it is difficult to determine whether a member is participating in relation to thought, not participating, which often leads to decentralization. Because a sentence that is out of context is complete, incomplete, unknown. From this point of view, we believe that the concept of «complete» means conditional, relative», taking the opinion about the axiom, we decided not to give many examples of this type of sentence:

1. My father, who died in the twentieth century, was a generous and wise man (Sh. Kumarova, Myn zhyldyk sagynysh).

2. Yesterday Baysalym was shocked by his dream (O. Sarsenbayev, Sheshen ali tiri).

3. The people also succeeded in talking about the cold days of the month of January (K. Ysakak, Sybaga).

The first sentence does not have a complement member, the «five guns» of the two subsequent sentences. And in terms of content, everything is in a quality that gives the reader complete information.

Incomplete definitions are given for the proposals in relation to incomplete sentence: all the thoughts expressed in relation to the members are inadmissible. And about the stylistic, grammatical nature of the word, scientists said: «Making a sentence incomplete is a way of economical pronunciation of the word. Making a sentence in incomplete form manifests itself in different ways, depending on the grammatical structure of the sentence, the context, and the state of speech. When forming a sentence in an incomplete form, all the members of the sentence can be removed», [3; 42] and: «... since the roll language (coherent speech) is more ambiguous, the sentence is flexible than in a full sentence, they are often used» $[1 ; 63]$.

The most frequently used among the sentences we considered were such incomplete structures:

1. Without delay he said that he will admit his shame (S. Hasan, Algys) (who?).

2. My lover, his title - yours, the benefit - mine (K. Segizbayev, Dos syry) (what?).

3. He has just come from a long way off (O. Sarsenbayev, Azhar) (whom?).

4. We met unexpectedly on the street (S. Balgabayev, Bari de este) (with whom?).

5. He had a dream (J. Musin, Omir sarkyramasy) (when?).

The sentences are based on stable, unstable type of members. For example, in the beginning there is not enough beginner, in the continuation of which-the speaker, in the third-definitions, in the subsequentadditions, improvements. At the same time, who is recognized, who encountered whom on the street, when he saw - everything remains unknown. And it is not difficult to understand the content of a sentence that is one of the words, such as, for example, what will be the general narrative for the names and initiators of the use.

Researchers, however, say that this type of sentence is «consumed much in speaking». Because of this specificity, incomplete sentences are often used in dialogue structures. Basically, it is an exchange of views between the addressee and the addressee, which often occur in the form of questions. And the main purpose of the conversation at the beginning is to tell the reader about what is happening in the story's history, about the characters, and what it is about:

- The bull shooter came back.

- What? How was he released so quickly?

- The Prosecutor released him himself. Stated he wasn't guilty (K. Zhoykinbekov, Ogiz atkan).

We are talking about news voiced by one of the two characters. It is usually created based on an exchange of views, rather than using a a question-and-answer method. The main character of the interview topic is the man who shot the bull, he is known not by his name, but by the type of perfect activity, that is, in the metonymic approach. The goal is to draw reader's attention to the incident. Consequently, the interview begins impressively. Another examples:

1. - The ash is ready?

- Look, maybe it is ready (T. Alzhanov, Shakshanyn tygyny).

2. - Do not come tomorrow.»

- No, I will come. Right here I will wait (B. Shakhanov, Synar syrga). 
There are no unnecessary words in the character's cues in the examples given. Both short and clearly formulated sentences are almost not fully filled. But impressively: when you read the first «What? why he needs the ashes, that's something unnecessary lying outside of any home?» and it's hard not to be surprised. When you read: with the same ash was prepared the nasybay, and there was a lottery ticket in it, he completely forgot, he came out a big win in the ticket, and everyone in the village could not find the winner. An example of this is an interview with the lines «don't come- I'll come» between a girl and a guy. The name of the story is «Synar syrga». «Do not come tomorrow» - these are the words of a person who was disappointed by something. The reader wants to know how it was, and the reason of the earring. Both replication and the theme are attractive. At this meeting, the guy played with one of the girl's earrings. But there was no way to return one of the earrings. In the end, when he himself became a family man, he looked at that earring and thought: "Living among people, and in this house, in his own bed, a person like this earring can live his lonely life». These examples show that « the author's personality, one of the stylistic approaches that demonstrate the signature of the writer, the speech and thinking of the characters». Another example:

- Mom, have you heard?

- About what?

- The daughter of Bekbergen, about the Erkesh.

- Yes, isn't she studying? (K. Amanov, Kygynshy kuda).

The interview consists of several lines that continue in this style. The peculiarity of this interview with the previous ones is that it is about a question that is unexpected. The word recourse (mom) is not only a word of attention. The interview begins with a conversation that says the girl who reads the «underground song before the wind» is marrying a guy who is studying.

In the examples below, the interview replica is presented with short, incomplete sentences. Impressive. The reason for this is that «In the short cut of sentences, most often a stylized goal is provided. The logical accent is short, even barefaced «[1;44].

The interview at the end of the conversation is basically the result of events, situations, and the conclusion of the content of the work. The syntax of these words are frequently used words that are associated with the idea, and also author's remarks:

1. - What do they say? The people are saying «It is a poet, he's a well-versed writer».

- How to say... I just wrote a song. "Oh, that's all!» said his neighbor (E. Konarbaev, Ondai zhasgyshtygyn ozine).

2. When saying goodbye:

- Come back anytime, my dear. We were all alone again, - he sighed

- All right, grandma, be healthy and get well soon.

-All right, right. You leaving us again. Goodbye! (K. Rakhimzhan, Dostar).

3. - That dog does not show his death, a good dog, - my dad said.

- As they say he was the best dog (J. Moldagaliev, Eskinin kozi).

The first example is a conversation between a neighbor and a hero who wrote poems in his own way, the second example is a conversation between a tenant and the owner, and the last example was an old man Kumai, who served the owner for seventeen years, and the father and son, took the dog to the place of death. The child spoke the words of the father.

In conclusion, we say: interviews that end the conversation have a great stylistic value. The final word that the author intends to say through the mouth of the characters, and through them the game begins to be logically solved.

Affirmative and negative sentences. Based on the conclusions: «volatility, underdevelopment manifests itself through the personality of the speakers» [3; 88], — in the initial proposals, there are also proposals whose content is insignificant: Kulyaykhan refused to leave the house (L. Omarova. Ak tailak).

Some negative sentences have an affirmative meaning:

1. «Kairak» the village was flooded and flowing into a flowing stream, and was never seen in the water deficit (T. Nurmagambetov, Synshy).

2. As he saw a large eyelid, a fur-bearing nose, and a large herd, Zhasulan did not pass his hand and greet him (B. Togysbayev, Akbilek).

3. There is nothing worse than migrating (K. Amanov, Habarlandyry).

4. The artist Zhanatay Shardenuly did not consider himself high in life (D. Doszhan. Alhimik).

5. Where does your way to the wilderness go? (S. Shaimerdenov, Altyn sagat). 
6. The name of Aktaspay in the named place does not remain one speech until the last male in this village (K. Muhanbetkaliuly, Zhalgys zhien).

In initial sentences, affirmative sentences are most often used. In this regard, Professor T. Abdigalieva, having studied the complex category of ignorance in the modern Kazakh language, noted: «Reality is a fundamental concept of life in human consciousness, at the same time, it is the root of the essence, meaning, and realization of space. That is why the verbal expression indicates that the act of a person with a sense of reality is made, and done in reality» — proves the most frequent use of affirmative sentences:

1. Manap fell ill on a business trip (O. Sarsenbayev, Kuralaydyn salkyny).

2. Only the person who has gone through the hassle of searching for an apartment can understand (M. Kanaz, It olimi).

3. The Syrym woke up with a buzzing sound of a clock (K. Jumadilov. Omir, sen tamashasyn).

Negative sentences in non-extended sentences:

1. Because of the frequent breathing of his sick wife, or because of the long conversation with the boss on that day, Askar could not sleep till the morning (K. Amanova, Kara shamadan).

2. You can't even dream of such a joke (M. Rakhmanberdiev, Silyk).

3. The dog that he was raising disappeared overnight (J. Ergali, Kumarlan).

4. I don't even know how I got into this situation (M. Omar, Tunilis).

5. Araeva could not sleep (L. Kurmanaeva, Umytpaimyn seni).

In the last sentences, there are also negative sentences expressed in the rhetorical form of an affirmative sentence, expressed by a person, an uncharacteristic and irreplaceable meanings:

1. There were many people on this street, many were lost!!? (K. Doszhan, Kokpar).

The final offers also consume offers to a small extent with a significant value: 1. Tengebai is not going to give up on his idea (M. Kanazov, Olermennin korshisi).

2. I do appreciate the simple art of this little girl (M. Imanzhanov, Kishkentai korshi).

3. I did not even regret that I did not take the chickens (A. Seydimbek, Tauga bitken zhalbyz).

Negative sentences in the last sentence:

1. Was it the sound of the mysterious Syrym's voice heard, or someone suddenly come here? Aybas could not detain him (A. Salykbaev, Kurdym).

2. But in a bed built against the wall, Zhaken could not feel anything (K. Zhusupov. Kara tunek).

3. The child who was waiting for his way did not even know that she could melt his father's heart of stone (D. Tuleuishev, Kogildir poezd).

4. After my father's words, I did not open my mouth (O. Sarsenbayev, ).

5. It's the reality, whether it's a dream or not, Bazarbek has not yet realized it (E. Konarbaev, Anmen arbay).

6. Today no one should wait for him (R. Seysenbaev, Zhalgyz gana tyn).

One component of the proposal. Depending on the compactness, intonation and other effective characteristics, their application is often applied.

Nominal sentences. The definition given about this type of offer is varied. For example, O.S. Akhmanova: «A single-component sentence composed in the nominative case from a noun in the nominative case or from a phrase meaning a number» $[2 ; 270]$ - classifies it into reported, fierce, demonstrative, existential (everyday) types.

And Professor Zh.A. Zhakypov, summarizing the main provisions about this type of sentence: «In the single-component sentence, there is no sense of presentation, emphasizes only the subject, phenomenon, address, period related to the event; only the intonation of the predicative message... The main condition of a nominal sentence is context... The clause practically does not meet the requirements of the sentence. It is divided depending on the pronunciation of the whole communicative whole (sentence) of the text (plan of expression)», which is completely separate from the thought.

Here are excerpts from other conclusions. The content of nominal sentences is related to the expression of a phenomenon in this period of existence. Therefore, they do not have past events, thoughts about the case, often periodically, we can call the phenomena of nature around us, the figurative position of objects $[6 ; 228]$.

«Nominal sentences are formulated with the need for a special communicative purpose. These sentences are used to describe the circle, the situation in an economical way, and as a way of emotional expression of opinion», - [3; 92 ], Professor R. Amir divides them into three groups: 1 . The visual values of 
the nominal sentence: Night. Precious moon. 2. Emotionally named sentences: laugh! 3. Cursing, meaningful phrase: You're tramp!

G. Temirbekova classifies nominal sentences for structural, semantic and communicative-functional tasks into four groups:1. Various types of life and everyday life, nominal sentences denoting an event: a) descriptive-speaker; b) descriptor. 2. Nominal offer of a broadcasting nature. 3. Emotional nominal sentence. 4. Link registered the offer [4; 15-17].

When we examine the materials we collected, it was significant and emotionally relevant to visualize a group of original sentences:

1. Night. One dark corner of the city (T. Abdykuly, Satsizdik).

2. Black autumn. Black gray sky (B. Kanatbayev, Tenizden esken zhel).

These are, of course, suggestions of content that are formulated under the pretext of the story's plot.

In the first example, in that the time of the event is described by a dark corner of the city, where there are many crimes, there is an emotional content in the soul of the reader that causes some kind of failure, evil, danger. In the second example from the description of nature, black paint reveals not a symbol of good, but still ahead of a negative action, a state. Therefore, this sentence is also negative emotionally. Indeed, like the theme, the first story («Satsizdik»), when the main character will end unsuccessfully, and the second one states that the situation will end indifferently.

While reading such initial nominal sentences, our impressions are not negative, as in the two examples above, but positive:

1. July. The weather in the city is hot (K. Rakhimzhan, Nukte).

2. Mountain. The steppe (K. Zhumalilov, Kazdar kaityp barady).

But the pictorial essence of this initial sentence does not affect the reader, but on the contrary, requires that it be further, and the desire to learn about the continuation of the conversation. This is due to the fact that this is the meaning, the content.

Thus, in these examples, we see that the original sentences of the story genre were used not only for simple compact, descriptive purposes but also in an emotional nature, as it positively affected the reader's perception of the story.

These scientists say: «Nominal sentences are often used in fiction as images of nature. They are used as a kind of stylistic way of describing being, and compact in the language of the writer», - proof of statements [5;228].

Let's pay attention to other examples: «Moonlit night. A night when a person can't make even the slightest sound» (N. Seraliev. Aptap). The emotional and expressive impression here was that «night» and «night when a person can't make even the slightest sound», characterized by a complex epithet equal to the author's structures.

In addition, in structural and semantic terms, there are places that were used in combination with the original nominal sentences: 1. The night without moon. The night without stars. Stormy night (A. Sataev. Topan). 2. Night. Fear, a dark night that leads to horror (R. Otarbayev. Tarki dunie).

The epiphora in them has a negative emotional meaning, both the recurring night and its definitions. At the same time, it does not only show the passage of the event or its past, place, or period of time, but also to describe man's actions with the environment, nature, and to let the reader predict how the conversation will end: The open sky. Slowly moving thin clouds. The grandfather and grandson loved Akboz's past, and he is also grateful to the present. (S. Gabbasov, Zhalgaskan omir).

The story formed according to the events that the proposals are set out from. Their content indicates that the right generation will continue and it will live carefreely, and this time Akboz can become the winner in the race.

If the original sentences formed by the name are perceived by syntax, emotionally from the semantic side, then the places of the last sentences that are nominal are rare. For example, the end of story "Azaly tyn» by D.Ramazan was formed so: "Yerzhan immediately understood what had happened. He fell to the cold floor crying at the sight of the gray face of his dead child...Inir. The steppe. The freeze".

In this sequence, the nominal sentences also indicate that the character's condition is so severe and miserable: Inir - a grief-stricken father who lost his son did not even notice the sunset. The steppe - an empty space that realized that he has no one else, the freeze - pressure "given" by fate.

Let's look at another example of the author: The dark night on which the Earth has captured the world. Dead peace (Mahabbat myny). 
These words alive, black, night, dead, silence-a narrow evil. It really happens: the hero hanged himself and dies.

There are also those who are formed in connection with historical periods in the initial and last nominal sentences, which are positively or negatively significant:

1. 1991. December 16. This is the day when the ten million Kazakhs, who have a great deal of land and have a window of equal value to others - the Republic of Kazakhstan (S. Hasan, Ashylmagan syr).

2. June 22, 1941. May 9, 1945. The first one was the German fascism's war against the peaceful nation, and the second one was the day when they was defeated by the whole world (K. Oljay, Zhenis kyn).

3. September 6, 1997, having 6 of stars (I. Eskarayevich, Ukim).

4. Spring of 1961 (T. Abdraiym, Mendi kyz).

5. October of 1966 (T. Abdraiym, Assel).

6. 1992. November. Brown autumn (T. Abdraiym, Bibijan).

7. July 1937. The twisted streets of Almaty (G. Kabyshuly, Konyr dapter).

Let's focus only on the last example. The writer decided to describe these times as «twisted», and therefore, uneven roads, zigzags-zigzags, indirect-in short it is unfair that, the hot month of July literally melts everyone.

Although these sentences are in a certain form, it should be understood that the internal content is the same as the underlying structure.

I.R. Halperin is synonymous with the terms subtext and implication: «although it is known that there is some difference among synonyms» [46; $46 \mathrm{p}]$. We believed that the suggestions we had made were notable.

\title{
References
}

1 Сыздық Р. Сөз құдіреті / Р. Сыздық. - Алматы: Санат, $199-224$ б.

2 Виноградов В. О языке художественной литературы / В. Виноградов. - М.: Гос. лит. изд-во, 1959. - 655 с.

3 Базарбаев М. Қазіргі қазақ көркем шығармаларының тілі / М. Базарбаев. - Алматы: Жазушы, 1986. - 57-66 бб.

4 Нұрмұқанов Х. Сөз және шеберлік / Х. Нұрмұқанов. - Алматы: Ғылым, 1987. — 288 б.

5 Қабдолов 3. Әдебиет теориясының негіздері / З. Қабдолов. - Алматы: Мектеп, 1970. — 380 б.

6 Оңалбаева К. Қазіргі қазақ тіліндегі есімді сөйлемдер / К. Оңалбаева. — Алматы, 2002. - 132 б.

7 Ақыжанова А. Қазақ тіліндегі парцелляция құбылысы (Бөлшектелген сөйлемдер) / А. Ақыжанова. — Алматы, 1999. -110 б.

8 Демесинова Н. Развитие синтаксиса современного казахского языка / Н. Демесинова. - Алма-Ата: Наука, 1974. $172 \mathrm{c}$.

9 Балақаев М. Қазіргі қазақ тілі грамматикасы. Синтаксис / М. Балақаев. - Алматы: Мектеп, 1971. — 338 б.

\author{
М.Қ. Жүнісова, А.Ж. Саяжанова
}

\section{Бастапқы және соңғы сөйлемдердің синтаксистік құрылымы}

\begin{abstract}
Мақалада мәтін құрауда синтаксистік ерекшеліктер негізгі шешуші қызмет атқаратыны талданған. Әңгіме жанрының бастапқы және соңғы сөйлемдері синтаксистік құрылымы жағынан әр алуан болып түзілетіні анықталды. Атап айтқанда, жай сөйлем түрлері, сөз-сөйлемдер, қыстырма сөз-сөйлемдер, құрмалас сөйлемдер мәтінтүзімде коммуникативтік, экспрессивтік, стилистикалық қызметтер атқаратыны қарастырылды. Атап айтқанда, ойды жарыққа шығаруда, түсінікті де ұғымды болу үшін оған лайықты семантикалы, ықшам құрылымдар, модальдылық, экспрессивтілік, стильдік шеберлік те осы сөйлемдердің түрлі құрылымдарына негізделетіні зерттелді. Басты нысан ретінде, бір құрамды не екі құрамды сөйлемдер ойды ықшам, қысқа, аз сөзді, қажетті ғана тұлғаларды ерекшелеу синтаксистік заңдылықтары нәтижесінде ғана әңгіме жанрының мәнінде іске асатыны баса назар аудартады. Әсіресе, бастапқы сөйлемдердің әр алуан болып түзілу ерекшеліктері айқындалды. Синтаксистік құрылымы жағынан бастапқы және соңғы сөйлемдер әр алуан болып: жалаң, жайылма, толымды, толымсыз, болымды, болымсыз; бір құрамдылардың барлық түрі олардың ішінде атаулы, вокатив сөйлемдер, сөз-сөйлемдер болып келеді. Дегенмен, мұндай позициядағылар күрделі сөйлемдерден болмай, көбіне ықшам, аз сөзді, ойға қатысты сөздері дәл іріктелген, басы артық сөзі жоқ жай сөйлемдер болып келеді. Бастапқы және соңғы сөйлемдердің семантика-синтаксистік сипаты бұлардың лепті, хабарлы, сұраулы, құрмалас түрлеріне байланысты баяндалды. Әсіресе бастапқы сөйлемдердегі сұраулы позициядағы сөйлемдердің риторикалы, қарсы сұрақты түрлерінің семантикалық ерекшеліктері айқындалды. Әңгіме жанрының атаулы құрылымды бастапқы сөйлемдерінің тек жай ықшамдық, суреттемелік қана мақсатта емес, шығарма желісінің белгілі бір
\end{abstract}


тұстарымен не әңгіменің жалпы мазмұнымен сабақтастырыла әрі оқырман сезіміне жағымдыжағымсыз әсер еткендей эмоциялық сипатта қолданылғанын көреміз. Сонымен бірге қаламгерлер бастапқы атаулы сөйлемдерінде оқиғаның өтетін не өткен мерзімін, жерін ғана, яғни мезгіл-мекенін ғана көрсетіп қоймайды, адамның іс-қимылын қоршаған ортамен, табиғатпен байланыстыра суреттеу арқылы да, оқырманға әңгіменің қалай аяқталатыны туралы алдын ала болжам жасауға мүмкіндік беретіні қарастырылды. Бастапқы және соңғы атаулы сөйлемдердің тарихи кезеңдерге байланысты жағымды-жағымсыз мәнді болып түзілгендері де кездесетіні айқындалды.

Кілт сөздер: синтаксистік ерекшеліктер, жай сөйлем, семантика, стильдік шеберлік, бастапқы сөйлемдер, соңғы сөйлемдер, мәтін, құрылым, синтаксистік заңдылық.

\section{М.К. Жунусова, А.Ж. Саяжанова}

\section{Синтаксическая структура начальных и конечных предложений}

В статье проанализирована ключевая роль синтаксических особенностей при составлении текста. Было определено, что первые и последние предложения текста синтаксически разнообразны. Словапредложения, простые, вводные и сложные предложения выполняют в тексте коммуникативные, выразительные и стилистические функции. Были изучены необходимые для раскрытия ясности и понятности идеи предложений семантические и сжатые структуры, модальность, выразительность и стилистическое мастерство, которые основаны на различных структурах этих предложений. Подчеркивается, что с помощью синтаксических законов посредством односоставных или двусоставных предложений, которые передают идею текста кратко и лаконично, раскрываются особенности персонажа. Определены особенности образования разнообразных начальных предложений. Синтаксическая структура начальных и конечных предложений различна: простые, неоднозначные, полные, неполные, положительные, отрицательные. Все типы односоставных компонентов являются именными, вокативными, нечленимыми предложениями. Однако такие предложения не являются сложными, в основном это простые короткие. Семантико-синтаксическая характеристика начальных и конечных предложений описывается в их идиоматических, повествовательных, вопросительных, сложных формах. Были определены семантические особенности риторических вопросов в начальных предложениях. Следует отметить, что номинальная структура начальных предложений текста используется не только для простоты описания, но и для эмоциональности, как если бы она была связана с определенными аспектами сюжета или общим содержанием рассказа и влияла на чувства читателя. Считается, что авторы в первоначальных предложениях не только указывают на время или место события, но также описывают поведение человека по отношению к окружающей среде и природе и тем самым позволяют читателю предсказать финал истории. Было определено, что начальные и конечные предложения, в зависимости от исторического периода, могут быть использованы как в положительном, так и отрицательном значении.

Ключевые слова: синтаксические особенности, простое предложение, семантика, стилистическое мастерство, начальные предложения, заключительные предложения, текст, состав, синтаксическая закономерность.

\section{References}

1 Syzdyk, R. (1995). Soz kudireti [The power of words]. Almaty: Sanat [in Kazakh].

2 Vinogradov, V. (1959). O yazyke khudozhestvennoi literatury [About the language of fiction]. Moscow: Hoslitizdat [in Russian].

3 Bazarbaev, M. (1986). Qazirhi qazaq korkem shygarmalarynyn tili [Language of modern Kazakh art works]. Almaty: Zhazushy [in Kazakh].

4 Nurmukanov, H. (1987). Soz zhane sheberlik [Word and skill]. Almaty: Gylym [in Kazakh].

5 Qabdolov, Z. (1970). Adebiet teoriiasynyn negizderi [Fundamentals of the theory of literature]. Almaty: Mektep [in Kazakh].

6 Onalbayeva, K. (2002). Qazirhi qazaq tilindegi esimdi soilemder [Suggestions for the name of the modern Kazak language]. Almaty [in Kazakh].

7 Akyzhanova, A. (1999). Qazaq tilindegi partselliatsiia kubylysy (Bolshektelhen soilemder) [The phenomenon of parcelling in the Kazakh language (divided sentences)]. Almaty [in Kazakh].

8 Demesinova, N. (1974). Razvitie sintaksisa sovremennoho kazakhskoho yazyka [Development of the syntax of the modern Kazakh language]. Almaty: Hylym [in Russian].

9 Balakayev, M. (1971). Qazirgi qazaq tili grammatikasy. Sintaksis [Grammar of the modern Kazakh language. Syntax]. Almaty: Mektep [in Kazakh]. 